Contemplating the Ancients 



\section{Audrey Spiro}

\section{Contemplating the Ancients}

\section{Aesthetic and Social Issues in Early Chinese Portraiture}


University of California Press

Berkeley and Los Angeles, California

University of California Press, Ltd.

Oxford, England

(C) I990 by Audrey Spiro

Library of Congress Cataloging-in-Publication Data Spiro, Audrey G.

Contemplating the ancients: aesthetic and social issues in early Chinese portraiture / Audrey Spiro.

p. $\mathrm{cm}$.

Bibliography: $p$.

Includes index.

ISBN 0-520-06567-0 (alk. paper)

I. Portraits, Chinese. 2. Art, Chinese-Three kingdoms-Sui Dynasty, 220-618. I. Title.

$\mathrm{N}_{7591 . \mathrm{C}_{5} \mathrm{~S} 65} 1990$

$704.9^{\prime} 42^{\prime} 095 \mathrm{I}$ - de20

$89-3$ I 5 IS

Printed in the United States of America

$\begin{array}{lllllllll}\text { I } & 2 & 3 & 4 & 5 & 6 & 7 & 8 & 9\end{array}$

The paper used in this publication meets the minimum requirements of American National Standard for Information Sciences - Permanence of Paper for Printed Library Materials, ANSI Z39.48-1984. 
For MES and JPS, with gratitude 
